\author{
Mariola Tracz \\ Zakład Dydaktyki Geografii \\ Tomasz Rachwal \\ Zakład Przedsiębiorczości i Gospodarki Przestrzennej \\ Instytut Geografii \\ Akademia Pedagogiczna w Krakowie
}

\title{
Przedmiot podstawy przedsiębiorczości - założenia realizacji a przygotowanie nauczycieli
}

Wprowadzony od 2002 r. do wszystkich typów szkół ponadgimnazjalnych nowy przedmiot - podstawy przedsiębiorczości, zgodnie z założeniami ma na celu nie tylko wyposażenie uczniów w wiedzę z zakresu funkcjonowania gospodarki rynkowej w warunkach nasilających się procesów globalizacji i integracji europejskiej, ale także ma służyć rozwijaniu umiejętności, które będą niezbędne uczniom w dorosłym, aktywnym życiu zawodowym. Zgodnie z zapisem podstawy programowej oraz w nawiązaniu do wypowiedzi wielu uczestników ogólnopolskich konferencji z przedsiębiorczości, podczas realizacji tego przedmiotu powinny być kształtowane u uczniów m.in. postawy aktywności, otwartości, kreatywności i podejmowania rozważnego ryzyka w realizowaniu własnej kariery zawodowej przy uwzględnieniu wartości etycznych (Zioło, Rachwał 2005, 2006). Postawy te składają się na szeroko rozumianą postawę przedsiębiorczości (Gabała 2005, Rachwał 2004a, 2005, 2006, Strumska-Cylwik 2005).

Wprowadzenie edukacji w zakresie przedsiębiorczości do systemu szkolnego opierało się na kilku podstawowych założeniach, z których tylko niektóre znalazły wyraz w odpowiednich aktach prawnych i zostały przynajmniej częściowo zrealizowane. Większość z nich miała charakter postulatywny i nie została wdrożona, chociaż zwracało na nią uwagę wielu autorów (Górz, Rachwał 2006, Juchnowicz 2006, Osuch, Osuch 2005, Tracz 2005, 2006). Często te niezrealizowane założenia należy uznać w świetle dyskusji z praktykami życia szkolnego, a więc metodykami i nauczycielami, za fundamentalne i wręcz niezbędne do prawidłowego przebiegu edukacji w zakresie przedsiębiorczości.

Oto najważniejsze założenia edukacji w zakresie przedsiębiorczości, zrealizowane i niezrealizowane:

1. Edukacja w zakresie przedsiębiorczości ma się odbywać w gimnazjum (moduł ,wychowanie do aktywnego udziału w życiu gospodarczym" - 1 godz. w cyklu kształcenia) i wszystkich typach szkół ponadgimnazjalnych (przedmiot podstawy przedsiębiorczości - 2 godz.). Niestety, to podstawowe założenie nie jest w pełni realizowane, gdyż w gimnazjum moduł ,wychowanie do aktywnego udziału w życiu gospodarczym" nie jest osobnym przedmiotem, lecz stanowi część przedmiotu wiedza o społeczeństwie. Konsekwencją jest to, że prowadzą go często nauczyciele niezbyt dobrze przygotowani (nie ukończyli studiów podyplomowych z przedsiębiorczości), którzy często marginalizują treści tego modułu, wypełniając go treściami związanymi z wiedzą obywatelską. Ponadto w zasadniczych szkołach zawodowych ten 
przedmiot jest realizowany tylko w wymiarze 1 godz. w cyklu kształcenia. Analiza obowiązującej podstawy programowej i nowego - przedstawionego przez MEN-jej projektu wskazuje, że podstawa programowa dla zasadniczej szkoły zawodowej jest nieco okrojoną wersją podstawy programowej dla szkół maturalnych. Nasuwa się więc pytanie, czy w przypadku przedmiotu podstawy przedsiębiorczości nie należałoby zrezygnować z tego podziału i stworzyć jednej podstawy programowej dla szkół ponadgimnazjalnych, przeznaczając na jego realizację co najmniej 2 godz. w cyklu kształcenia we wszystkich typach szkół. Jest to tym bardziej istotne, że ten przedmiot ma przygotowywać uczniów do życia we współczesnym świecie, stąd niecelowe wydaje się założenie, że uczniowie szkół zawodowych powinni być wyposażeni w tę umiejętność w mniejszym stopniu. Wręcz przeciwnie, ze względu na to, że wielu absolwentów szkół zawodowych (w przeciwieństwie do absolwentów szkół kończących się maturą) bezpośrednio po ukończeniu szkoły rozpoczyna życie zawodowe (szuka zatrudnienia bądź zakłada własną firmę), w przypadku szkół zawodowych powinno się dążyć do rozszerzania zakresu treści programowych i przeznaczenia na nauczanie tego przedmiotu większej liczby godzin. Na marginesie należy zaznaczyć, że nietrafna jest decyzja autorów III wersji projektu podstawy programowej o włączeniu w zasadniczej szkole zawodowej treści z zakresu przedsiębiorczości w ramy przedmiotu wiedza o społeczeństwie. Będzie to prowadzić do ich całkowitej marginalizacji (tak, jak to ma miejsce w gimnazjum), szczególnie jeśli w wyniku takich zmian przedmiot będzie w całości realizowany przez nauczyciela WOS, który nie odbył studiów podyplomowych w zakresie nauczania przedsiębiorczości ani żadnych innych studiów o profilu ekonomicznym (Górz, Rachwał 2006).

2. Wprowadzenie nowych treści wymaga więc stworzenia odpowiedniej podstawy programowej. Obecnie obowiązująca podstawa jest daleka od doskonałości i nie odpowiada współczesnym wyzwaniom edukacyjnym. Nowa propozycja, mimo że jest krokiem milowym naprzód, wymaga szerokiej dyskusji w gronie specjalistów i dopracowania. Za zupełnie niezrozumiałe należy uznać próby likwidacji tego przedmiotu bądź ograniczenia treści kształcenia z zakresu przedsiębiorczości. Należy pamiętać, że przedsiębiorczość jest jednym z kluczowych przedmiotów w europejskim wymiarze nauczania i należy do podstawowych umiejętności w strategii edukacyjnej UE (Tracz 2006). Jak słusznie zauważa wielu autorów, w fazie informacyjnej rozwoju cywilizacyjnego o konkurencyjności człowieka i - w konsekwencji - całej gospodarki w największym stopniu będą decydować zasoby kapitału ludzkiego. Są one czynnikiem, bez którego nie jest możliwe osiagnięcie trwałego i wysokiego tempa rozwoju społeczno-gospodarczego (Borowiec 2003, Janc 2003, Kołodziejski 1998). Kluczowe jest więc ukształtowanie w procesie edukacyjnym konkurencyjnego człowieka, cechującego się postawą przedsiębiorczą. Jak zauważa Z. Zioło (2005a), tylko konkurencyjny człowiek jest w stanie wyprodukować i zaoferować konkurencyjny produkt. Edukacja w zakresie przedsiębiorczości powinna zatem zostać rozszerzona na niższe szczeble edukacji. Wydaje się bowiem, że ukształtowanie postawy przedsiębiorczości i konkurencyjnego we współczesnym świecie człowieka jest możliwe tylko dzięki realizacji celów z zakresu kształtowania postaw przedsiębiorczych na wszystkich szczeblach edukacji i na różnych przedmiotach, a nie tylko na nowo wprowadzonym w szkołach ponadgimnazjalnych przedmiocie podstawy przedsiębiorczości. Konieczne jest więc dostrzeżenie przez wychowawców i nauczycieli innych przedmiotów - począwszy od nauczycieli kształcenia zintegrowanego w szkole podstawowej - roli, jaką mają do spełnienia w kształtowaniu postaw przedsiębiorczych uczniów (Rachwał 2006).

3. Edukacja w zakresie przedsiębiorczości nie jest możliwa bez wykształcenia kompetentnych nauczycieli tego przedmiotu. Poza sporadycznymi pilotażowymi cyklami bezpłatnych studiów podyplomowych, finansowanymi przez MEN, kształcenie w tym zakresie zrzucono na 
barki nauczycieli, tworząc $\mathrm{w}$ dodatku bariery biurokratyczne dla nauczycieli przedmiotów ekonomicznych, od których zaczęto wymagać ukończenia studiów z przedsiębiorczości. Jednocześnie zaniedbano całkowicie problem nauczycieli w szkołach gimnazjalnych, zakładając, że nauczyciel WOS sam dokształci się w zakresie nowego modułu. Często to dokształcanie nie było realizowane, gdyż nie wymagano od nauczycieli formalnego ukończenia studiów podyplomowych. Skutkiem zaniechania działań przygotowujących kadry nauczycielskie do realizacji nowych zadań jest stosunkowo słabe przygotowanie merytoryczne nauczycieli, o czym świadczą (omówione niżej) wyniki badań prowadzonych wśród nauczycieli. Ponadto należy podkreślić, że zgodnie ze strategią lizbońską nauczanie tego przedmiotu to zadanie nie tylko dla nauczyciela przedsiębiorczości, ale także dla całej społeczności szkolnej. W Polsce ta idea praktycznie nie jest realizowana, oprócz szkół, w których pracują wyjątkowo przedsiębiorczy i wyjątkowo społecznie nastawieni nauczyciele, gotowi bez dodatkowego wynagrodzenia organizować specjalne zajęcia pozalekcyjne i konkursy przedsiębiorczości czy przygotowywać uczniów do olimpiad.

4. Do edukacji w zakresie przedsiębiorczości potrzebne są specjalne warunki organizacyjne, m.in. dostęp do pracowni komputerowych i mobilnych zestawów multimedialnych (który bardzo często jest ograniczony tylko do nauczycieli technologii informacyjnej), organizacja specjalnych pracowni symulacyjnych (istnieją w nielicznych szkołach, bo brak środków na ich organizację), podział klasy na małe grupy wynikający ze specyfiki przedmiotu, na którym wyposaża się ucznia przede wszystkim w umiejętności, co wymaga pracy w grupach liczących 8-12 osób, konieczność organizacji częstych ćwiczeń terenowych, zajęć pozalekcyjnych itp. (bariery organizacyjne i finansowe).

5. Pozostaje nierozstrzygnięta sprawa matury z podstaw przedsiębiorczości. Należy zauważyć, że jej wprowadzenie jest opóźniane ze względu na liczne kontrowersje natury merytorycznej i trudności organizacyjne, do których przeciwnicy wprowadzenie matury z tego przedmiotu zaliczają (Rachwał 2006):

- sprzeczność z istotą przedsiębiorczości;

- trudności w określaniu kryteriów sprawdzania umiejętności;

- konieczność ograniczenia liczby przedmiotów na maturze (według koncepcji zakładającej, że na maturze powinno się sprawdzać wiedzę i umiejętności tylko z przedmiotów o charakterze ogólnokształcącym);

- nieporównywalność zakresu wymagań z innymi przedmiotami;

- zmniejszenie atrakcyjności przedmiotu w oczach uczniów;

- zmniejszenie zaangażowania uczniów na lekcjach ze względu na konieczność realizowania przez nauczycieli materiału ,pod kątem” matury;

- mniejsza swoboda nauczycieli w doborze treści kształcenia;

- niebezpieczeństwo odejścia od kształcenia umiejętności na rzecz wyposażania uczniów w wiedzę o charakterze ekonomicznym i tym samym przekształcenie przedmiotu w ,podstawy ekonomii";

- konieczność przeczekania „chaosu organizacyjnego” związanego z przeprowadzaniem „,nowej matury";

- brak odpowiedniej liczby dobrze przygotowanych nauczycieli przedsiębiorczości (szczególnie w zakresie przygotowania uczniów do matury na poziomie rozszerzonym);

Należy jednak przytoczyć istotne argumenty zwolenników jej wprowadzenia (por. Bartoń 2005):

- poszerzenie katalogu przedmiotów maturalnych do wyboru dla uczniów;

- możliwość uzyskania na świadectwie dojrzałości oceny z przedmiotu o charakterze ekonomicznym; 
- możliwość oceny kandydatów dla uczelni ekonomicznych;

- wyeliminowanie dodatkowego egzaminu wstępnego z podstaw przedsiębiorczości w uczelniach ekonomicznych;

- standaryzowanie wymagań;

- większy prestiż przedmiotu w strukturze nauczania szkoły;

- większe zaangażowanie uczniów na lekcjach (ze względu na świadomość, że przedmiot jest objęty sprawdzianem zewnętrznym);

- większa szansa na zwiększenie liczby godzin w cyklu kształcenia, szczególnie w obliczu zbyt małej liczby godzin (1-2 w cyklu kształcenia) na realizację treści wynikających z rozbudowanej podstawy programowej tego przedmiotu;

- zwiększenie roli edukacji o charakterze ekonomicznym w oczach społeczeństwa;

- popularyzacja postaw przedsiębiorczych w społeczeństwie.

Należy się więc zgodzić ze stanowiskiem M. Bartonia (2005) że - podążając za doświadczeniami innych krajów, w tym krajów europejskich - przedmiot podstawy przedsiębiorczości powinien zostać uznany za przedmiot maturalny, szczególnie wobec tego, że w założeniach nowej matury uczniowie mogą zdawać takie przedmioty, jak historia muzyki czy filozofia (od 2008 r.).

Funkcjonowanie nowego przedmiotu staje się okazją do refleksji nad jego wdrożeniem w systemie kształcenia i nad kompetencjami nauczycieli. Podjęto w tym celu badania diagnostyczne, mające na celu zebranie i analizę danych o realizacji założeń reformy oświaty w odniesieniu do podstaw przedsiębiorczości. Celem badań było:

- ustalenie poziomu kwalifikacji merytorycznych i dydaktycznych nauczycieli uczących podstaw przedsiębiorczości,

- poznanie opinii nauczyciela przedsiębiorczości o formach kształcenia,

- poznanie opinii nauczycieli o wprowadzeniu podstaw przedsiębiorczości do szkół ponadgimnazjalnych.

Badaniami ankietowymi objęto 215 nauczycieli podstaw przedsiębiorczości z ośmiu województw: lubelskiego, łódzkiego, małopolskiego, podkarpackiego, podlaskiego, śląskiego, wielkopolskiego i zachodniopomorskiego. Ankieta zawierała 20 pytań, w tym 15 zamkniętych i 5 otwartych. Badania przeprowadzono wśród nauczycieli wszystkich typów szkół ponadgimnazjalnych (tab. 1). Najliczniejszą grupę badanych stanowili nauczyciele liceów ogólnokształcących - 61 osób, czyli 28,4\%, oraz zespołu szkół: ponadgimnazjalnych (liceum profilowane, technikum, zasadnicza szkoła zawodowa) - 36 osób, czyli 16,7\%, i ogólnokształcących (liceum ogólnokształcące, liceum profilowane, technikum) - 31 osób, czyli 14,5\%.

Dane wskazuja, że $46,5 \%$ badanych nauczycieli prowadzi zajęcia z podstaw przedsiębiorczości w dwóch lub trzech szkołach. Wynika to m.in. z liczby godzin przeznaczonych na nauczanie tego przedmiotu oraz liczby klas w danym typie szkoły. W realizacji procesu dydaktycznego nie jest to korzystna sytuacja, szczególnie wtedy, kiedy szkoły są od siebie znacznie oddalone. Dojazdy powodują stratę czasu, który nauczyciele mogliby przeznaczyć na lepsze przygotowanie się do lekcji. Poza tym taka sytuacja sprawia, że nauczyciele w mniejszym stopniu identyfikują się z jedną, konkretną szkołą i tym samym rzadziej podejmują dodatkowe działania na jej rzecz.

Zawód nauczyciela wymaga odpowiednich kwalifikacji - gruntownego przygotowania merytorycznego i dydaktycznego oraz odpowiednich cech osobowych. Jak do nauczania podstaw przedsiębiorczości przygotowany jest nauczyciel? Wyniki badań wskazują, że nauczyciele podstaw przedsiębiorczości w 82,4\% ukończyli magisterskie studia wyższe w trybie stacjonarnym (dzienne), tylko 2 osoby, czyli niecały 1\% badanych legitymuje się ukończeniem tylko studiów licencjackich I stopnia (tab. 2). 
Tab. 1. Nauczyciele uczący podstaw przedsiębiorczości według województw i typu szkoły

\begin{tabular}{|c|c|c|c|c|c|c|c|c|c|c|c|}
\hline Wyszczególnienie & LO & $\mathbf{L P}$ & $\mathbf{T}$ & ZSZ & $\begin{array}{c}\text { LO, } \\
\text { LP }\end{array}$ & $\begin{array}{c}\text { LO, } \\
\text { LP, T }\end{array}$ & $\begin{array}{c}\text { LP, T, } \\
\text { ZSZ }\end{array}$ & $\begin{array}{c}\text { T, } \\
\text { ZSZ }\end{array}$ & $\begin{array}{c}\text { Szko- } \\
\text { ty } \\
\text { po- } \\
\text { lice- } \\
\text { alne }\end{array}$ & $\begin{array}{c}\text { Ra- } \\
\text { zem }\end{array}$ & $\begin{array}{c}\text { Udzial } \\
\text { woj. w } \\
\text { liczbie } \\
\text { ogółem } \\
\text { (w \%) }\end{array}$ \\
\hline Lubelskie & 9 & 1 & 4 & 1 & 3 & 7 & 4 & 0 & 1 & 30 & 14,0 \\
\hline Łódzkie & 11 & 1 & 4 & 0 & 5 & 1 & 9 & 3 & 2 & 36 & 16,7 \\
\hline Małopolskie & 10 & 1 & 6 & 1 & 2 & 10 & 5 & 2 & 3 & 40 & 18,6 \\
\hline Podlaskie & 8 & 2 & 2 & 0 & 3 & 2 & 4 & 0 & 0 & 21 & 9,8 \\
\hline Podkarpackie & 3 & 4 & 6 & 0 & 1 & 3 & 4 & 1 & 0 & 22 & 10,2 \\
\hline Śląskie & 9 & 0 & 2 & 0 & 0 & 2 & 3 & 7 & 3 & 26 & 12,1 \\
\hline Wielkopolskie & 6 & 2 & 2 & 1 & 3 & 3 & 3 & 1 & 1 & 22 & 10,2 \\
\hline Zachodniopomorskie & 5 & 0 & 2 & 2 & 2 & 3 & 4 & 0 & 0 & 18 & 8,4 \\
\hline Razem & 61 & 11 & 28 & 5 & 19 & 31 & 36 & 14 & 10 & 215 & 100,0 \\
\hline $\begin{array}{l}\text { Udział typu szkoły } \\
\text { w liczbie ogółem } \\
(w \%)\end{array}$ & 28,4 & 5,1 & 13,0 & 2,3 & 8,8 & 14,4 & 16,7 & 6,5 & 4,7 & 100,0 & $\mathbf{x}$ \\
\hline
\end{tabular}

Źródło: opracowanie autorów na podstawie ankiet

Wyjaśnienie skrótów: LO - liceum ogólnokształcące, LP - liceum profilowane, T - technikum, ZSZ - zasadnicza szkoła zawodowa

Tab. 2. Kwalifikacje zawodowe nauczycieli podstaw przedsiębiorczości

\begin{tabular}{|l|c|c|c|c|}
\hline Wyszczególnienie & $\begin{array}{c}\text { Studia } \\
\text { magisterskie } \\
\text { dzienne }\end{array}$ & $\begin{array}{c}\text { Studia } \\
\text { magisterskie } \\
\text { zaoczne }\end{array}$ & $\begin{array}{c}\text { Studia } \\
\text { Studia } \\
\text { licencjackie }\end{array}$ & $\begin{array}{c}\text { podyplomowe } \\
\text { z podstaw } \\
\text { przedsiębiorczości }\end{array}$ \\
\hline Lubelskie & 22 & 8 & 0 & 14 \\
\hline Łódzkie & 31 & 5 & 0 & 16 \\
\hline Małopolskie & 34 & 6 & 0 & 16 \\
\hline Podlaskie & 19 & 2 & 0 & 14 \\
\hline Podkarpackie & 20 & 2 & 1 & 11 \\
\hline Śląskie & 24 & 2 & 1 & 10 \\
\hline Wielkopolskie & 14 & 7 & 0 & $\mathbf{1 0 3}$ \\
\hline Zachodniopomorskie & $\mathbf{1 7 8}$ & $\mathbf{3 6}$ & $\mathbf{2}$ & $\mathbf{4 7 , 9}$ \\
\hline Razem & $\mathbf{8 2 , 8}$ & $\mathbf{1 6 , 7}$ & $\mathbf{0 , 9}$ & \\
\hline $\begin{array}{l}\text { Udział nauczycieli } \\
\text { kończących dany typ } \\
\text { studiów w ogólnej } \\
\text { liczbie badanych } \\
\text { (w \%) }\end{array}$ & & & & \\
\hline
\end{tabular}

Źródło: opracowanie autorów na podstawie ankiet 
Większość badanych ukończyła studia ekonomiczne - 90 osób (41,5\%). Są oni absolwentami kierunków ekonomicznych akademii ekonomicznych, uniwersytetów i akademii rolniczych. Następną grupę stanowią absolwenci kierunków nieekonomicznych: matematyki, fizyki, informatyki - 18 osób (8,3\%), geografii - 15 osób (6,9\%), historii - 6 osób $(2,7 \%)$, pedagogiki - $5(2,3 \%)$ i innych - 81 osób (38,3\%). Najwięcej nauczycieli podstaw przedsiębiorczości po studiach ekonomicznych uczy w województwach: małopolskim (15 osób), podkarpackim (13 osób), lubelskim (10 osób) i wielkopolskim (10 osób). Jest to m.in. skutek funkcjonowania w tych województwach silnych ośrodków akademickich, zwłaszcza akademii ekonomicznych.

W ramach doskonalenia zawodowego 103 nauczycieli spośród badanych $(47,9 \%)$ ukończyło studia podyplomowe z podstaw przedsiębiorczości. Absolwentami studiów podyplomowych są głównie osoby, które nie ukończyły studiów ekonomicznych. Dane wskazują, że znaczna część nauczycieli uczących podstaw przedsiębiorczości nie podjęła doskonalenia zawodowego związanego z nauczaniem nowego przedmiotu. Studia ekonomiczne na wyższych uczelniach na ogół dobrze przygotowują z wybranych specjalności ekonomicznych, jednak treści kształcenia zawarte $\mathrm{w}$ podstawie programowej i programach nauczania podstaw przedsiębiorczości nie są prostym przełożeniem treści ekonomicznych do szkoły. Wiedza zawarta w podstawie programowej ma charakter zintegrowany i obejmuje zagadnienia z zakresu funkcjonowania gospodarki i rynku pracy, instytucji oraz komunikacji interpersonalnej jako całości (Tracz 2005, Rachwał 2004b).

Podstawowe znaczenie dla aktualizacji wiedzy nauczyciela ma zatem samokształcenie. Powinno ono się odbywać m.in. dzięki dostępowi do książek, czasopism, konferencji i seminariów, audycji telewizyjnych, internetu. Wydaje się potrzebą chwili powołanie do życia czasopisma dla nauczycieli podstaw przedsiębiorczości, które popularyzowałoby osiagnięcia naukowe z zakresu objętego podstawą programową oraz nowatorskie, warte upowszechnienia rozwiązania metodyczne dotyczące programu nauczania, podręczników szkolnych, metod kształcenia i środków dydaktycznych. Częściowo tę lukę wypełniają seminaria metodyczne organizowane przez wydawnictwa oraz różnego typu fundacje i stowarzyszenia (np. Fundację ,Edukacja dla Społeczeństwa"). Znaczącą rolę do odegrania mają Stowarzyszenie Nauczycieli Przedsiębiorczości oraz kluby, takie jak IMPULS stworzony przez Narodowy Bank Polski.

W jakim kierunku powinno zatem zmierzać przygotowanie nauczyciela do nauczania tego przedmiotu? Ankietowani nauczyciele wskazali kilka rozwiązań. Niemal 50\% badanych uważa, że nauczyciel podstaw przedsiębiorczości powinien ukończyć studia magisterskie dwuprzedmiotowe $(33,9 \%)$ lub magisterskie jednolite z podstaw przedsiębiorczości $(14,8 \%)$. Jedna czwarta badanych jest zdania, że przygotowanie powinno się odbywać poprzez doskonalenie, czyli studia podyplomowe z podstaw przedsiębiorczości (tab. 3).

Nauczyciele nie są zwolennikami studiów I stopnia (licencjackich) z podstaw przedsiębiorczości. Wydaje się być dobrym rozwiązaniem, z punktu widzenia realizacji założeń reformy oświaty, powołanie na niektórych kierunkach specjalności ,przedsiębiorczość” w uniwersytetach i akademiach pedagogicznych, co gwarantowałoby przygotowanie do zawodu nauczyciela w pełnym zakresie. Jest to ważne, bo przepisy nie pozwalają na uruchomienie samodzielnego kierunku studiów ,przedsiębiorczość”, nie ma go bowiem w obowiązującym wykazie ministerialnym kierunków kształcenia. Na studiach wyższych możliwe jest więc tylko uruchamianie przedsiębiorczości jako specjalizacji. Taka specjalizacja jest realizowana m.in. na kierunku „geografia” w Akademii Pedagogicznej w Krakowie (Zioło 2005b). Wydaje się więc celowe umożliwienie uruchomienia studiów na kierunku ,przedsiębiorczość”.

Istotne jest pytanie o motywy wyboru tego przedmiotu przez nauczycieli. Wśród czynników, które decydowały o tym najczęściej, wymieniano kwalifikacje, głównie ukończone studia ekonomiczne (34,9\% badanych), a następnie uzupełnianie godzin brakujących do wypełnienia etatu, 
Tab. 3. Formy przygotowania nauczyciela podstaw przedsiębiorczości w opinii badanych

\begin{tabular}{|l|c|c|c|c|c|c|c|}
\hline & $\begin{array}{c}\text { Studia } \\
\text { magis- } \\
\text { terskie } \\
\text { z 2 przed- } \\
\text { miotów }\end{array}$ & $\begin{array}{c}\text { Studia } \\
\text { magis- } \\
\text { terskie } \\
\text { z podstaw } \\
\text { przedsié- } \\
\text { biorczości }\end{array}$ & $\begin{array}{c}\text { Studia } \\
\text { licen- } \\
\text { cjackie } \\
\text { 2 przed- } \\
\text { miotów }\end{array}$ & $\begin{array}{c}\text { Studia } \\
\text { licen- } \\
\text { cjackie } \\
\text { z podstaw } \\
\text { przedsié- } \\
\text { biorczości }\end{array}$ & $\begin{array}{c}\text { Studia } \\
\text { pody plo- } \\
\text { mowe } \\
\text { z podstaw } \\
\text { przedsié- } \\
\text { biorczości }\end{array}$ & $\begin{array}{c}\text { Studia } \\
\text { ekono- } \\
\text { miczne }\end{array}$ & $\begin{array}{c}\text { zrak } \\
\text { zdania }\end{array}$ \\
\hline Lubelskie & 10 & 2 & 0 & 0 & 11 & 2 & 4 \\
\hline Lódzkie & 12 & 2 & 0 & 2 & 9 & 6 & 5 \\
\hline Małopolskie & 16 & 8 & 0 & 2 & 9 & 4 & 2 \\
\hline Podlaskie & 6 & 6 & 0 & 0 & 11 & 1 & 0 \\
\hline Podkarpackie & 9 & 3 & 2 & 0 & 4 & 1 & 3 \\
\hline Śląskie & 7 & 5 & 3 & 3 & 4 & 1 & 4 \\
\hline Wielkopolskie & 8 & 2 & 2 & 1 & 5 & 1 & 0 \\
\hline $\begin{array}{l}\text { Zachodnio- } \\
\text { pomorskie }\end{array}$ & $\mathbf{7 3}$ & 1 & 0 & 1 & 7 & 2 & 2 \\
\hline Razem & $\mathbf{2 9}$ & $\mathbf{7}$ & $\mathbf{9}$ & $\mathbf{6 0}$ & $\mathbf{1 8}$ & $\mathbf{1 9}$ \\
\hline $\begin{array}{l}\text { Udzial nauczycieli } \\
\text { wyrażających daną } \\
\text { opinię w ogólnej } \\
\text { liczbie badanych } \\
\text { (w \%) }\end{array}$ & $\mathbf{3 4 , 0}$ & $\mathbf{1 3 , 5}$ & $\mathbf{3 , 3}$ & $\mathbf{4 , 2}$ & $\mathbf{2 7 , 9}$ & $\mathbf{8 , 4}$ & $\mathbf{8 , 8}$ \\
\hline
\end{tabular}

Źródło: opracowanie autorów na podstawie ankiet

wynikające z wprowadzonej reformy systemu edukacji, która zmniejszyła ogólną liczbę godzin do przepracowania dla nauczycieli w szkole (26,5\%). Tylko 19,5\% nauczycieli wskazało własne zainteresowania, a 19,2\% nie udzieliło odpowiedzi (tab. 4).

Tab. 4. Czynniki wpływające na podjęcie nauczania podstaw przedsiębiorczości

\begin{tabular}{|l|c|c|c|c|}
\hline Wyszczególnienie & Zainteresowanie & $\begin{array}{c}\text { Wykształcenie } \\
\text { ekonomiczne }\end{array}$ & $\begin{array}{c}\text { Uzupełnienie } \\
\text { etatu }\end{array}$ & Brak odpowiedzi \\
\hline Lubelskie & 5 & 12 & 8 & 14 \\
\hline Łódzkie & 7 & 15 & 8 & 16 \\
\hline Małopolskie & 5 & 16 & 8 & 16 \\
\hline Podlaskie & 4 & 9 & 7 & 14 \\
\hline Podkarpackie & 4 & 3 & 3 & 9 \\
\hline Śląskie & 8 & 6 & 10 & 13 \\
\hline Wielkopolskie & 5 & 10 & 5 & 11 \\
\hline Zachodniopomorskie & 4 & 4 & 8 & $\mathbf{1 0 3}$ \\
\hline Razem & $\mathbf{4 2}$ & $\mathbf{7 5}$ & $\mathbf{5 7}$ & $\mathbf{1 9 , 1}$ \\
\hline $\begin{array}{l}\text { Udział nauczycieli } \\
\text { wyrażających daną } \\
\text { opinię w ogólnej } \\
\text { liczbie badanych } \\
\text { (w \%) }\end{array}$ & $\mathbf{1 9 , 5}$ & $\mathbf{3 4 , 9}$ & $\mathbf{2 6 , 5}$ & \\
\hline
\end{tabular}

Źródło: opracowanie autorów na podstawie ankiet 
Niski udział zainteresowania wśród powodów decyzji o podjęciu nauczania przedmiotu jest niekorzystny z punktu widzenia realizacji procesu dydaktycznego. Oznacza on pewną przypadkowość w podejmowaniu nauczania podstaw przedsiębiorczości, wynikającą z wykształcenia, chęci uzyskania dodatkowych godzin lub wewnętrznego przymusu spowodowanego sytuacją życiowa. Może to ujemnie wpływać na jakość kształcenia.

Potwierdzeniem są wyniki analizy stażu pracy w zawodzie nauczyciela. W ankietowanej grupie blisko 30\% stanowili nauczyciele z ponaddwudziestoletnim stażem pracy. Drugą pod względem liczebności byli nauczyciele początkujący w zawodzie - 21,2\% (tab. 5). Najliczniejszą grupę nauczycieli podstaw przedsiębiorczości z najdłuższym stażem odnotowano w województwach małopolskim (20 osób) i łódzkim (15 osób). Największą grupę wśród badanych nauczycieli o najniższym stażu pracy odnotowano w województwach: podkarpackim (10 osób) i lubelskim (8 osób).

Tab. 5. Staż pracy nauczycieli podstaw przedsiębiorczości

\begin{tabular}{|l|c|c|c|c|c|}
\hline Wyszczególnienie & $\mathbf{0 - 5}$ lat & $\mathbf{6 - 1 0}$ lat & $\mathbf{1 1 - 1 5}$ lat & $\mathbf{1 6 - 2 0}$ lat & Powyżej 20 lat \\
\hline Lubelskie & 8 & 7 & 7 & 4 & 4 \\
\hline Łódzkie & 4 & 5 & 4 & 8 & 15 \\
\hline Małopolskie & 8 & 5 & 5 & 2 & 20 \\
\hline Podlaskie & 2 & 4 & 7 & 2 & 6 \\
\hline Podkarpackie & 10 & 7 & 1 & 2 & 2 \\
\hline Śląskie & 4 & 2 & 6 & 6 & 8 \\
\hline Wielkopolskie & 5 & 3 & 4 & 5 & 5 \\
\hline Zachodniopomorskie & 4 & 4 & 5 & 1 & 4 \\
\hline Razem & $\mathbf{4 5}$ & $\mathbf{3 7}$ & $\mathbf{3 9}$ & $\mathbf{3 0}$ & $\mathbf{6 4}$ \\
\hline $\begin{array}{l}\text { Udział nauczycieli } \\
\text { poszczególnych grup } \\
\text { wiekowych w ogólnej } \\
\text { liczbie badanych } \\
\text { (w \%) }\end{array}$ & $\mathbf{2 0 , 9}$ & $\mathbf{1 7 , 2}$ & $\mathbf{1 8 , 1}$ & $\mathbf{1 4 , 0}$ & $\mathbf{2 9 , 8}$ \\
\hline
\end{tabular}

Źródło: opracowanie autorów na podstawie ankiet

Od nauczyciela, który z konieczności prowadzi zajęcia, trudno oczekiwać motywowania uczniów i rozbudzania ich zainteresowania poznawanymi treściami. Wydaje się zatem konieczne podjęcie badań specyfiki zawodowej nauczyciela podstaw przedsiębiorczości i umiejętności, które powinien opanować w toku studiów.

Kolejnym badanym zagadnieniem była ocena wprowadzenia przedmiotu podstawy przedsiębiorczości do szkół ponadgimnazjalnych. Większość ankietowanych (89\%) uważa, że było ono słuszne, tylko 9,7\% badanych nie miało zdania. Podobne opinie na tak postawione pytanie - w świetle wcześniejszych badań prowadzonych w krakowskich szkołach (Osuch, Osuch 2005) wyrazili badani uczniowie i rodzice. Za wprowadzeniem odrębnego przedmiotu podstawy przedsiębiorczości w gimnazjum było 60,0\% nauczycieli (130 osób), a 25,1\% (54 osoby) nie mało sprecyzowanego zdania. Przeciwko wprowadzeniu przedmiotu podstawy przedsiębiorczości w gimnazjum było 14,4 \% ankietowanych (tab. 6). Dane potwierdzają, że edukację w zakresie przedsiębiorczości należy rozszerzyć na niższe poziomy edukacji. Treści wzbudzające największe zainteresowanie wśród uczniów to w opinii nauczycieli: komunikacja interpersonalna, prawo pracy, rynek pracy, zarządzanie przedsiębiorstwem, przygotowanie biznesplanu i funkcjonowanie 
banków. Najwięcej trudności-zdaniem nauczycieli-uczniowie mają z funkcjonowaniem gospodarki rynkowej, wypełnianiem formularzy oraz podatkami i rachunkowością przedsiębiorstwa.

Tab. 6. Opinia nauczycieli o wprowadzeniu podstaw przedsiębiorczości do szkół

\begin{tabular}{|l|c|c|c|c|c|c|}
\hline \multirow{2}{*}{ Wyszczególnienie } & \multicolumn{2}{|c|}{ Tak } & \multicolumn{2}{c|}{ Nie } & \multicolumn{2}{c|}{ Nie mam zdania } \\
\cline { 2 - 7 } & ogółem & \% & ogółem & \% & ogółem & $\%$ \\
\hline $\begin{array}{l}\text { Czy wprowadzenie podstaw przedsiębior- } \\
\text { czości do szkoły było słuszne? }\end{array}$ & 193 & 89,0 & 1 & 0,3 & 21 & 9,7 \\
\hline $\begin{array}{l}\text { Czy w gimnazjum powinien być wprowadzo- } \\
\text { ny przedmiot podstawy przedsiębiorczości? }\end{array}$ & 130 & 60,0 & 31 & 14,4 & 54 & 25,1 \\
\hline $\begin{array}{l}\text { Czy podstawy przedsiębiorczości powinny } \\
\text { być do wyboru na maturze? }\end{array}$ & 133 & 62,0 & 30 & 14,0 & 52 & 24,0 \\
\hline
\end{tabular}

Źródło: opracowanie autorów na podstawie ankiet

O pozycji i randze przedmiotu szkolnego, oprócz kwalifikacji zawodowych nauczyciela, decyduje m.in. liczba godzin przeznaczonych na jego realizację oraz możliwość zdawania go na maturze. Większość badanych nauczycieli uważa, że liczba godzin przeznaczonych na nauczanie podstaw przedsiębiorczości w stosunku do założeń programowych jest za mała; możliwość realizowania treści przewidzianych programem nauczania dawałyby 3 lub 4 godziny tygodniowo. W opinii $62 \%$ ankietowanych, uczniowie powinni móc wybierać podstawy przedsiębiorczości na egzaminie maturalnym (tab. 6). Przeciwko umieszczeniu podstaw przedsiębiorczości na liście przedmiotów maturalnych było $14,0 \%$ badanych, a $24,0 \%$ nie miało sprecyzowanego zdania. Wprowadzeniem podstaw przedsiębiorczości do grupy przedmiotów do wyboru na egzaminie maturalnym najbardziej zainteresowani są nauczyciele liceów profilowanych i techników. Uważają oni, że zdawanie tego przedmiotu dałoby ich wychowankom szansę dostania się na studia ekonomiczne (gdyby oczywiście wynik maturalny z podstaw przedsiębiorczości stanowił kryterium kwalifikacyjne). Wynika to $\mathrm{z}$ faktu, że uczniowie liceów profilowanych i techników mogą przeznaczyć mniej czasu na przedmioty ogólne (np. matematykę) niż uczniowie liceów ogólnokształcących, co skutkuje nieco słabszymi wynikami na egzaminie maturalnym z przedmiotów, które są obecnie brane pod uwagę przez uczelnie ekonomiczne (w zależności od uczelni są to z reguły: matematyka, język obcy, historia, WOS bądź geografia). Wprowadzenie matury z podstaw przedsiębiorczości zwiększyłoby więc szanse uczniów tego typu szkół na zdanie matury oraz dostanie się na studia na podstawie wyniku egzaminu maturalnego z przedmiotu, którego zakres kształcenia jest zbliżony do kilku przedmiotów zawodowych realizowanych w technikach i liceach profilowanych.

Wyniki badań potwierdzają potrzebę przeprowadzenia dyskusji nad efektywnością realizacji założeń wprowadzenia podstaw przedsiębiorczości do szkół. Należy podjąć badania, których wyniki powinny dać podstawę do opracowania modelowej sylwetki nauczyciela podstaw przedsiębiorczości. Trzeba również opracować formy doskonalenia i samokształcenia nauczycieli tego przedmiotu odpowiadające wymogom stawianym współczesnej szkole, chociażby w formie e-learnigu. Bez rozpoczęcia takich działań na szeroką skalę trudno będzie mówić o świadomej i celowej edukacji młodzieży z podstaw przedsiębiorczości.

\section{Literatura}

1. Bartoń M., 2005, Przedsiębiorczość jako przedmiot matury 2008 [w:] Przedsiębiorczość a wspótczesne wyzwania cywilizacyjne, Z. Zioło, T. Rachwał (red.), seria: Przedsiębiorczość - Edukacja nr 1, 
Zakład Przedsiębiorczości i Gospodarki Przestrzennej IGAP w Krakowie, Wydawnictwo „MiWa”, Kraków

2. Borowiec M., 2003, Ksztaltowanie się krakowskiego ośrodka akademickiego w latach 1960-2001 [w:] Geograficzne aspekty globalizacji i integracji europejskiej, M. Śmigielska, J. Słodczyk (red.), Wydawnictwo PTG, Uniwersytet Opolski, Opole

3. Gabała J., 2005, Ksztaltowanie postaw przedsiębiorczych uczniów [w:] Przedsiębiorczość a wspótczesne wyzwania cywilizacyjne, Z Zioło, T. Rachwał (red.), seria: Przedsiębiorczość - Edukacja nr 1, Zakład Przedsiębiorczości i Gospodarki Przestrzennej IGAP w Krakowie, Wydawnictwo „MiWa”, Kraków

4. Górz B., Rachwał T., 2006, Uwagi do projektu zmiany podstawy programowej podstaw przedsiębiorczości [w:] Rola przedsiębiorczości w podnoszeniu konkurencyjności społeczeństwa i gospodarki, Z. Zioło, T. Rachwał (red.), seria: Przedsiębiorczość - Edukacja $n r$ 2, Wydawnictwo Nowa Era, Zakład Przedsiębiorczości i Gospodarki Przestrzennej IGAP w Krakowie, Warszawa-Kraków

5. Janc K., 2003, Rola nauki i techniki we współczesnym świecie [w:] Geograficzne aspekty globalizacji i integracji europejskiej, M. Śmigielska, J. Słodczyk (red.), Wydawnictwo PTG, Uniwersytet Opolski, Opole

6. Juchnowicz M., 2006, Uwagi dotyczace realizacji przedmiotu podstawy przedsiębiorczości [w:] Rola przedsiębiorczości w podnoszeniu konkurencyjności społeczeństwa i gospodarki, Z. Zioło, T. Rachwał (red.), seria: Przedsiębiorczość - Edukacja nr 2, Wydawnictwo Nowa Era, Zakład Przedsiębiorczości i Gospodarki Przestrzennej IGAP w Krakowie, Warszawa-Kraków

7. Kołodziejski J., 1998, Strategiczna koncepcja przekształceń polskiej przestrzeni a wyzwania cywilizacyjne XXI w. [w:] Współczesne problemy rozwoju regionalnego, T. Marszał i M. Opałło (red.), Biuletyn KPZK PAN, Warszawa, z. 180

8. Makieła Z., 2004, Nowy przedmiot nauczania dla geografów - podstawy przedsiębiorczości [w:] Ksztatcenie i doskonalenie nauczycieli geografii w Polsce $i$ w krajach Unii Europejskiej w drodze do jednoczqcej się Europy, Wydawnictwo Naukowe AP w Krakowie, Kraków

9. Osuch E., Osuch W., 2005, Przedmiot podstawy przedsiębiorczości w opinii uczniów i rodziców na przykładzie wybranych krakowskich szkót [w:] Przedsiębiorczość a wspótczesne wyzwania cywilizacyjne, Z. Zioło, T. Rachwał (red.), seria: Przedsiębiorczość - Edukacja nr 1, Zakład Przedsiębiorczości i Gospodarki Przestrzennej IGAP w Krakowie, Wydawnictwo „MiWa”, Kraków

10. Podstawa programowa kształcenia ogólnego (dla liceum ogólnokształcqcego, liceum profilowanego i technikum), Rozporządzenie Ministra Edukacji Narodowej i Sportu z 26.02.2002 r., Warszawa

11. Przedsiębiorczość a współczesne wyzwania cywilizacyjne, Z. Zioło, T. Rachwał (red.), seria: Przedsiębiorczość - Edukacja nr 1, Zakład Przedsiębiorczości i Gospodarki Przestrzennej IG Akademii Pedagogicznej w Krakowie, Wydawnictwo „MiWa”, Kraków

12. Rachwał T., 2004a, Kształtowanie postaw przedsiębiorczych u uczniów - wyzwaniem dla nauczycieli geografii [w:] Kształcenie i doskonalenie nauczycieli geografii w Polsce i w krajach Unii Europejskiej $w$ drodze do jednoczacej się Europy, Wydawnictwo Naukowe AP w Krakowie, Kraków

13. Rachwał T., 2004b, Cele i treści kształcenia przedsiębiorczości w szkołach ponadgimnazjalnych [w:] Przedsiębiorczość stymulatorem rozwoju gospodarczego, J. Brdulak, M. Kulikowski (red.), Instytut Wiedzy SGH, Warszawa

14. Rachwał T., 2005, Ksztaltowanie postaw uczniów na lekcjach podstaw przedsiębiorczości [w:] Przedsiębiorczość a współczesne wyzwania cywilizacyjne, Z. Zioło, T. Rachwał (red.), seria: Przedsiębiorczość - Edukacja nr 1, Zakład Przedsiębiorczości i Gospodarki Przestrzennej IG AP w Krakowie, Wydawnictwo „MiWa”, Kraków

15. Rachwał T., 2006, Ksztaltowanie postaw przedsiębiorczych w edukacji szkolnej [w:] Szkoła w nauce i praktyce edukacyjnej, t. II, B. Suchacka (red.), Oficyna Wydawnicza „Impuls”, AP w Krakowie, Kraków

16. Rola przedsiębiorczości w podnoszeniu konkurencyjności społeczeństwa i gospodarki, Z. Zioło, T. Rachwał (red.), seria: Przedsiębiorczość - Edukacja nr 2, Nowa Era i Zakład Przedsiębiorczości i Gospodarki Przestrzennej IG AP w Krakowie, Warszawa-Kraków

17. Strumska-Cylwik L., 2005, Rozważania nad zagadnieniem przedsiębiorczości w kontekście otwartości człowieka na świat [w:] Przedsiębiorczość a wspótczesne wyzwania cywilizacyjne, Z. Zioło, T. Rachwał (red.), seria: Przedsiębiorczość - Edukacja nr 1, Zakład Przedsiębiorczości i Gospodarki Przestrzennej IG AP w Krakowie, Wydawnictwo „MiWa”, Kraków 
18. Tracz M., 2005, O niektórych kryteriach doboru treści nauczania do podstawy programowej i programu nauczania podstaw przedsiębiorczości [w:] Przedsiębiorczość a współczesne wyzwania cywilizacyjne, Z. Zioło, T. Rachwał (red.), seria: Przedsiębiorczość - Edukacja nr 1, Zakład Przedsiębiorczości i Gospodarki Przestrzennej IG AP w Krakowie, Wydawnictwo „MiWa”, Kraków

19. Tracz M., 2006, Rola i znaczenie „podstaw przedsiębiorczości” w ksztatceniu ogólnym [w:] Rola przedsiębiorczości w podnoszeniu konkurencyjności społeczeństwa i gospodarki, Z. Zioło, T. Rachwał (red.), seria: Przedsiębiorczość - Edukacja nr 2, Nowa Era i Zakład Przedsiębiorczości i Gospodarki Przestrzennej IG AP w Krakowie, Warszawa-Kraków

20. Zioło Z., 2005a, Światowe uwarunkowania rozwoju przedsiębiorczości [w:] Przedsiębiorczość a wspótczesne wyzwania cywilizacyjne, Z. Zioło, T. Rachwał (red.), seria: Przedsiębiorczość - Edukacja nr 1, Zakład Przedsiębiorczości i Gospodarki Przestrzennej IG Akademii Pedagogicznej w Krakowie, Wydawnictwo „MiWa”, Kraków

21. Zioło Z., 2005b, Ksztatcenie nauczycieli do nauczania przedsiębiorczości na specjalności „, geografia z przedsiębiorczościq i gospodarkq przestrzenna" w Akademii Pedagogicznej w Krakowie [w:] Przedsiębiorczość a wspótczesne wyzwania cywilizacyjne, Z. Zioło, T. Rachwał (red.), seria: Przedsiębiorczość - Edukacja nr 1, Zakład Przedsiębiorczości i Gospodarki Przestrzennej IG AP w Krakowie, Wydawnictwo „MiWa”, Kraków

\section{Basis of Entrepreneurship Lessons - Assumption About Realization vs. Preparation of Teachers}

The implementation of an education about an entrepreneurship to Polish educational system was based on some fundamental assumptions, but only few of them were recognized in the legal acts and partly realized. More of them have a form of postulate and were not implemented; although many experts pointed at their significance. After discourse with practitioners from schools, i.e. methodologists and teachers, most of unrealized assumptions have to be considered as fundamental and essential to proper progress of the education about the entrepreneurship. In the first part of the article the most important conditions of effective education about the entrepreneurship - both realized and waiting for implementation - were presented. Great emphasis were putted on controversial problem of including this subject in Matura exam. The functioning of the new subject is a opportunity to reflect on its implementation to the educational system, and on a competency of teachers. Therefore in the second part of the paper, the study of results of the survey conducted among entrepreneurship teachers was presented. Survey aimed at:

- identify the level of essential and didactical competences among the entrepreneurship teachers.

- identify teacher's opinion on the forms of education

- identify teacher's opinion on the introducing the basis of entrepreneurship to secondary schools.

The results confirm the need of debate about the efficiency of the implementation the assumptions about the introducing the basis of entrepreneurship to schools. Research should be conducted on the model profile of the entrepreneurship teacher. Also new forms of education and self-education for the teachers are needed to meet requirements for modern school - for example e-learning. 